\title{
Od církve zkoumající znamení doby (GS 4) k církvi rozlišujuící (EG 43)
}

\section{Pavel Ambros}

\section{Znamení doby bez světla evangelia a se světlem evangelia}

Je současná teologie součástí církve zkoumající znamení doby? Je současný teolog zasvěcen službě rozlišování? V př̌ednášce papeže Františka na Katolické univerzitě v Buenos Aires formou videoposelství zazní velmi silně požadavek prekonání rozvodu mezi teologií a pastorací. Rozhodujícím momentem je stále sílící církevní vědomí potřebnosti „zakořenit, vtělit, prezentovat se a interpretovat víru tvárí v tvář životu“. To je současným posláním církve. Po teologovi dneška požaduje papež František tř̌i věci: a) být „, první řadě synem svého lidu“, což ho vede $\mathrm{k}$ „uznání, že věřící lid, ve kterém se narodil, má teologický význam, který nemůže ignorovat. Ví, že byl naroubován na církevní vědomí, a hrouží se do oněch vod“; b) „být věříím“, totiž „mít zkušenost“ a „smýšleni““ Ježíše Krista; c) „být prorokem“, totiž „udržovat naživu vědomí minulosti i pozvání přicházející z budoucnosti“.

Zde můžeme cítit odezvu toho, co na samém počátku II. vatikánskému koncilu vyjádřil Jan XXIII. výrazem aggiornamento. Tímto výrazem označil ve své řeči ze dne 25 . ledna 1959 potřebu reformy Kodexu církevního práva. ${ }^{2}$ Ve stejném proslovu oznamuje svolání Římské synody a ekumenického koncilu. Použitý italský výraz, jen stěží přeložitelný do oficiální latiny koncilních dokumentů i do jiných moderních jazyků, vnáši do života církve nový prvek. Nejedná se o adaptaci církve rozvinutou $\mathrm{v}$ soudobých teoriích křestanských misií nebo o zavádění nových reformních kroků, nýbrž o novou pastorační citlivost k tomu, co přináší dnešek. Dủvod je jediný: zohlednit „perspektivu dobra duší (bonum animarum) a s ním těsně spjatou a zřetelně určenou linii nového pontifikátu - duchovní potřeby přítomné chvíle“.3

Proslavil se výrok samotného papeže Jana XXIII.: „Katolická církev není muzeum starožitností. Je jako starý pramen u vesnice, který dává vodu dnešním generacím, jako ji dával předešlým. ${ }^{\text {“4 }}$ Každý den (giorno) přináší odpovídající povinnosti. Poznání a přijetí těchto povinností, které se stávají mravně závazné, pastorační imperativy, jsou oním aggiornamentem zvláště tehdy, když dnešek přináší bolestné situace.

1 FRANCESCO, Il fiume vivo. In un videomessaggio alla facoltà teologica dell'Università cattolica argentina il Papa ricorda il Vaticano II e sottolinea il collegamento dinamico fra tradizione ricevuta e realtà concreta, in: L'Osservatore Romano (5. 9. 2015), s. 8; (v českém překladu: ( ) Překonat rozvod teologie s pastorací.Přednáška papeže na Katolické univerzitě v Buenos Aires (formou videoposelství on-line), dostupné na: http://www.radiovaticana.cz/podrubrika.php4?id=13), citováno dne 15. 9. 2015. Srov. IOANNES XXIII., Sollemnis allocutio, Acta apostolicae sedis 51/1959, s. 68. 
„Církev je svědkyní vážné vnitřní krize lidské společnosti. Lidstvo je na prahu nové éry; proto odpovědné a nesmírné úkoly čekají církev podobně jako v nejtragičtějších údobích jejích dějin. Jde o to sdělit životodárné, věčné energie evangelia dnešnímu světu, který se honosí svými vymoženostmi na poli techniky a vědy, ale který též v sobě nese následky toho, že někteří chtěli reformovat časný řád odezírajíce od Boha. ${ }^{“ 5}$

Všechno toto, co působí smutek a úzkost, je součástí života Kristových učedníků od samého počátku a je spojeno s Ježíšovou osobou i životem prvotní církve. Jan XXIII. pokračuje:

„Tyto bolestné okolnosti nám připomínají povinnost bdít. Navíc udržují živým náš smysl pro odpovědnost. Lidé zbavení naděje vidí jen temnoty, prý úplně pohltily zemi. Naproti tomu my chceme všem povědět o nezdolné důvěře v našeho Spasitele, který neopustil lidi, jež vykoupil. Právě naopak, přijímáme za svou výzvu Krista Pána, abychom uměli rozlišovat ,znamení doby' (Mt16,3); zdá se nám, že vidíme uprostřed tak velké temnoty nemálo znamení, vedoucích $\mathrm{k}$ důvěře v budoucnost církve a lidstva.“6

Základní intuice Jana XXIII. je vtisknuta do jiného výrazu - i segni dei tempi (znamení časů). Papež svoji důvěru opírá o biblický odkaz z Matoušova evangelia: „Vzhled oblohy tedy umíte posoudit, a znamení časů ne?" (Mt 16,3b), z nějž pak dovozuje nekončící Boží ochranu nad dějinami i údělem člověka. Jak upozorňuje Marie-Dominique Chenu († 1990), výraz znamení doby vstoupil do hovorového jazyka, když byla publikována 11. dubna 1963 encyklika Pacem in terris. Navíc encyklika významně zasáhla do prŕípravných prací XVII. schématu, z nějž se zrodila pastorální konstituce Gaudium et spes. Dokonce se vážně uvažovalo o tom, že tento okružní list je možné převzít beze změn nebo jej předložit jako základ koncilního jednání.7 V oficiálním latinském originálu se výraz znamení doby vůbec neobjevil. V italské verzi se objevil čtyřikrát, vždy jako údaj o pozitivním směřování lidské společnosti. ${ }^{8}$ Výraz sám se stal nositelem programového obsahu. Vstupuje nově na pole teologie jako jednání vyrůstající z morální analýzy situace, která obrací člověka k vnitřně závaznému jednání. Dává $a k c i$, praxi a lidskému rozhodování novou perspektivu. ${ }^{9}$ Rodí se nová citlivost a pochopení praxe církve. ${ }^{10}$

Pavel VI. oba výrazy spojuje: aggiornamento a znamení doby jsou programem, který hledá formy pastorační činnosti, které odpovídají stavu dnešního člověka a mohou být dnešním člověkem přijaty. Ta ovšem nespočívá ve snaze „se v nejlepším úmyslu přiblížit co nejsnadněji k lidovým masám a jednotlivým společenským třídám“, ve snaze „přizpůsobit se jim a ne se od nich lišit proto, aby tímto nedůstojným spodobením dodali své činnosti důraz a účinnost“. Platí i pro ni těžce uskutečnitelný výrok „abychom byli na tomto světě, ale ne z tohoto světa“. ${ }^{11} \mathrm{O}$ to silněji v ní zaznívá i zaslíbení stvrzené Kristovou modlitbou k Otci za nás: „Neprosím, abys je ze světa vzal,

\footnotetext{
IOANNES XXIII., Humanae salutis 3, Acta apostolicae sedis 54/1962, s. 6.

Tamtéž, 4, s. 7.

Srov. Karel SKALICKÝ, Radost a naděje, Řím: Křestanská akademie, 1968, s. 40, pozn. 2.

Srov. Marie-Dominique CHENU, Les signes des temps, Nouvelle Revue Théologique 87/1965, s. 30, pozn. 2.

Srov. tamtéž, s. 29-30.

10 Kněží „at’ ochotně naslouchají laikům, bratrsky zvažují jejich přání a uznávají jejich zkušenosti i odbornou př́slušnost v různých oblastech lidské činnosti, aby společně s nimi dovedli rozpoznávat znamení doby. Při zkoumání duchů, zdali jsou z Boha, (srov. 1J 4,1) at citem víry odkrývají rozličné dary laiků, jak malé, tak i významnější, a s radostí at je uznávají i pečlivě podporuji" (Presbyterorum ordinis 9); „mezi znameními naší doby zaslouží zvláštní zmínku rostoucí a nepotlačitelný cit solidarity všech národů. Je úkolem apoštolátu laiků, aby tento cit neúnavně podporoval a přetvářel v upř́mné a pravé bratrské cítění (Apostolicam actuositatem 9); „pro tento posvátný sněm vybízí všechny katolické věrící, aby pochopili znamení doby a horlivě se účastnili ekumenického díla“ (Unitatis redintegratio 4$)$.

11 PAVEL VI., Ecclesiam suam, 49
} 
ale abys je zachránil od Zlého.“ (J 17,15) Přes toto „riziko“ je aggiornamento Pavlem VI. předloženo jako „pevné a všeobecně platné pravidlo“ „stále znovu a znovu burcujíć její stále obnovenou vitalitu“. ${ }^{12}$ Aggiornamento je pro církev pobídkou, stimulem „růstu schopnosti pohotově a bděle číst znamení doby,“ „aby její stále mladá a svěží horlivost vždy a všude všechno zkoumala a dobrého se držela $(1 \mathrm{Te} 5,21)^{\text {“. }}{ }^{13}$

Pro koncil začala být důležitá nejen otázka, co je církev ad intra, jak rozumí sama sobě, nýbrž jaká je její situace ve světě a především možnost účinné př́tomnosti ad extra ${ }^{14}$ Angelo Giuseppe Roncalli spojil své životní zkušenosti do tohoto sjednocujícího pohledu na katolickou církev ad intra a ad extra. Rok po svém svěcení se stal osobním sekretářem bergamského biskupa Giacoma Radini-Tedeschiho († 1914), angažovaného v katolickém sociálním hnutí, které se později přetavilo v Katolickou akci. Na krátkou dobu byl dokonce nařčen z modernismu. ${ }^{15}$ Po jeho smrti krátce učil církevní dějiny, aby poté, když vypukla první světová válka, prožil hrůzy války jako zdravotník v armádě. Podobně důležitá byla pro něj i zkušenost papežského vyslance v Bulharsku (1925-1933) a Turecku a Řecku (1934-1944). Co znamená Ǩím z pohledu Konstantinopole, se pro něj stalo druhým polem, které postavil do popředí zájmu koncilu. Tato pozice hledání postavení církve ad intra a ad extra jej přivádí ke světu, ve kterém církev žije plodné i dramatické napětí radosti a bolesti, naděje a úzkosti. Zkušenost válečné a poválečné Francie, včetně jeho osobních intervencí ve prospěch Židů ze Slovenska a Bulharska, ${ }^{16}$ jen jeho vidění světa znásobilo. V duchu italské rosminovské tradice vidí na jedné straně pět ran ukřižovaného Krista v imperialismu, marxismu, pokrokářské demokracii, zednářství a sekularismu, na straně druhé možnost obnovy skrze pastorační nasazení. Jeho pohled na znamení doby zahrnoval dovršené eschatologické křestanství bez doprovodné bezútěšné apokalyptiky. ${ }^{17}$ Znamení doby však nemohla být jen obnovenou verzí ŕímského vox temporis, vox Dei, ale křestanským hledáním vyváženého hlediska mezi extrémním eurocentrismem, globálním skepticismem a falešnou či přehnanou nekritickou fascinací optimismem světa ${ }^{18}$ Podle Bernarda Häringa „může být optimismus ke světu falešný a nebezpečný, není-li doprovázen ještě jiným nasměrováním, totiž duchem chudoby a odříkáním". ${ }^{19}$

Důležitý posun vnesl do př́pravy návrhu švýcarský kalvinistický teolog Lukas Vischer († 2008), reprezentující Světovou radu církví. Poukázal na dủležitost konceptu signa temporum (znamení časů) jako klíče k interpretaci celého následujícího textu. Pojetí času jako znamení a hlasu je problematické v tom, že neukazuje způsob, jímž Bůh jimi promlouvá. Ptá se, jak se má rozlišit Boží hlas od hlasu, který klame. Čas je z biblického hlediska jev mnohoznačný a interpretace dějin spásy na to neustále poukazují. Samotný Ježíš odmítá zjednodušenou četbu Boží prozřetelnosti, jak se ukazuje v jeho sporu se současníky (L 11,29-32). V podobném duchu hovoří papež František o rozdílu mezi Jonášovým syndromem a Jonášovým znamením. ${ }^{20}$ Vischer ukázal na to, že v návr-

12 Tamtéž, 52.

13 Tamtéž.

14 Srov. Charles MOELLER, Pastoralkonstitution über die Kirche in der Welt von heute, in:Lexikon für Theologie und Kirche. Das zweite vatikanische Konzil. Konstitutionen, Dekrete und Erklärungen, Freiburg - Basel - Wien: Herder, 1968, s. 247.

15 Srov. Fausto FONZI, I cattolici e la società italiana dopo l'Unità, Roma: Studium, 1953, s. 90-115.

16 Srov. @ La Fondazione Wallenberg certificherà l'aiuto di Giovanni XXIII agli ebrei, Zenit. Il mondovisto da Roma (on-line), dostupné na: http://www.zenit.org/it/articles/la-fondazione-wallenberg-certifichera-l-aiuto-di-giovanni-xxiii-agli-ebrei, citováno dne 20.11. 2015.

17 Srov. GIOVANNI XXIII., Scritti e discorsi 1953-1958, 2, Roma: Edizioni paoline, 1959-1962, s. $28-42$.

18 Srov. Evangelista VILANUOVA, Intersession (1963-1964), in: Thehistory of Vatican II. Vol. III: The mature council. Second period and intersession (September 1963 - September 1964), eds. Giuseppe ALBERIGO - Joseph A. KOMONCHAK, New York - Leuven: Orbis Peeters, Maryknoll, 2000, s. 410-413.

19 Tamtéž, s. 410 (citace B. Häringa).

20 Srov. FRANCESCO, La sindrome di Giona, L'Osservatore Romano 153/236 (15. 10. 2013), s. 7. 
hu je zcela opomenut eschatologický aspekt znamení času. Proto navrhuje vylepšení a rozšíření, protože „nabízí příliš nevinný obraz světa, a proto nemůže zprostředkovat světu skutečnou naději“. ${ }^{21}$ Josef Ratzinger krátce shrnuje celou diskuzi ve svém komentáři, když hovoří o hermeneutické otázce s tím spojené, totiž jak spojit pohled antického vnímání vox temporis, vox Dei s biblickým

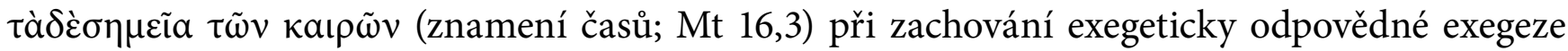
Ježíšova eschatologického varování těm, kteří znamení doby nerozeznávají. „Není právě Kristus jako skutečné znamení doby protikladem k zúčtování s časem (chronos), jak zaznívá ze slov vox temporis?"22 Tato rozevírající se propast křestanského a nekřestanského vnímání radosti a úzkosti, naděje a smutku, je ošetřena v závěrečné verzi návrhu dodatkem zkoumat a vykládat znamení doby ve světle evangelia. Kerygmatický charakter textu se opírá o poukaz na moudrost, která ví, že „Duch Páně naplňuje svět, a ten, který vše obsahuje, ví o všem, co se mluví (Mdr 1,7). Před církví se čas v tomto smyslu odhaluje jako kairos, který musí být zároveň dia-krisis těch, jimž byla sňata rouška ze srdce $(2 \mathrm{~K} 3,15)$. Opakem jsou „tupí, protože až dodneška u nich trvá stejná rouška, když se čte Starý zákon, a není jim odhaleno, že přestává v Kristu“ $(2 \mathrm{~K} 3,14) .{ }^{23}$ Text jde radikálně dále, když předpokládá to, co bylo nejvlastnějším charismatickým zřením Jana XXIII.: „To neplatí jen pro křestany, ale pro všechny lidi dobré vůle, v jejichž srdci neviditelně působí milost. " 24 Zde se rodí onen začátek začátku připomínající Eliáše putujícího širou pouští, aby se přiblížil na Boží horu. „Kdybychom proto unavení, malátní a rozmrzelí odpočívali pod kručinkou koncilního triumfalismu, “ ř́ká Rahner ve své přednášce 12. prosince 1965, pět dnů po ukončení koncilu, „pak nás bude moci či muset probudit $\mathrm{z}$ našeho spánku anděl Boží skrze děsivá nebezpečí a útrapy této doby, skrze pronásledování, odpad a bolesti srdce a ducha; pozdvihni se, větší část cesty máme ještě před sebou. ${ }^{\text {"25 }}$ Církev se po koncilu plaví na jedné lodi s lidstvem, s nímž snímá z očí roušku lidským nadějím i úzkostem, dodejme „s lidmi kolísajícími mezi nadějí a úzkosti““. ${ }^{26}$

\section{Na palubě lodi s lidmi kolísajícími mezi nadějí a úzkostí}

Nejedná se nám v tomto příspěvku o historicko-teologickou rekonstrukci široké rozpravy na téma znamení doby. Ani se zde nemůžeme zabývat obdobně bohatou recepcí koncilního textu. Spíše se zaposloucháme do jednoho dílč́ho ohlasu tradice, navozeného obrazem archy Noemovy. Totiž jeden z výroků, který koncilovou diskuzi o schématu XIII. s názvem De ecclesia in mundo huius temporis provázel, označil předlohu „za archu Noemovu, do které byly umístěny provizorně všechny náměty, které se nedaly umístit jinde“. ${ }^{27}$ Obraz sám chtěl vyjádřit zřejmě něco jiného, ale ukázal na povahu diskuze. ${ }^{28}$ Napětí mezi převládajícím optimismem a programovým dialektickým př́stupem ukazuje na jeden skrytý paradox textu: jeho rozdílné sociologické a teologické důrazy. Výsledný text nebyl integrací obou přístupů, nýbrž nalezenou shodou, zaujetím juxtapozice. ${ }^{29}$ Sdílí kulturní atmosféru doby doznívající moderny:

21 Nach der dritten Session des zweiten Vatikanischen Konzils, Reformatio 2/1965, s. 78-88.

22 Joseph RATZINGER, Ersten Kapitel des ersten Teils, in: Lexikon für Theologie und Kirche. Das zweite vatikanische Konzil. Konstituonen, Dekrete und Erklärungen, Freiburg - Basel - Wien: Herder, 1968, s. 313.

23 Tamtéž, s. 314.

24 Dokumenty II. vatikánského koncilu, Kostelní Vydř́i: Karmelitánské nakladatelství, 2002. Pastorální konstituce Gaudium et spes 22. Dále pouze GS a číslo př́slušného oddílu.

25 Karl RAHNER, Das Konzil - ein neuer Beginn, Freiburg - Basel - Wien: Herder 1966, s. 21-22.

26 GS 4.

27 Charles MOELLER, Pastoralkonstitution über die Kirche in der Welt von heute, s. 261.

28 Srov. Karel SKALICKÝ, Radost a naděje, s. 57-58.

29 Srov. Evangelista VILANUOVA, Intersession (1963-1964), s. 403. 
„Lidský rozum rozšiřuje v jistém smyslu svou nadvládu i nad časem: do minulosti pomocí historického bádání a do budoucnosti metodickým předvídáním a plánováním. Pokrok v biologii, psychologii a v sociálních vědách poskytuje člověku nejen možnost lepšího poznání sebe, ale také mu pomáhá, aby použitím technických metod př́mo ovlivňoval život společenských celků. Lidstvo se také stále více zabývá předvídáním a řízením svého demografického růstu. ${ }^{\text {"30 }}$

Tento pozitivní pohled na svět není novostí. Křestané vždy museli čelit světu plnému nepřátelských postojů. Př́běhy mučedníků a vyznavačů svědčí o Boží síle v dějinách, ale i o zbabělosti či nedostatku svobody přilnout ke Kristu. Církev zná i prŕběhy slabosti, hanbu hříšnosti křestanů. Podobně čelila s větším či menším zdarem i riziku korupce s mocnými tohoto světa. I zde napsaly dějiny církve své světlé i stinné, zahanbující i stud zraňující události. Přesto cílem křestanského života je přetvářet čas, zachytit věčné v časném, „protože věčnost není něco, ale je to někdo, nebo lépe řečeno, je to věčná láska tří Osob “. ${ }^{31}$ Poslední slovo nemá smrt. Čas je totiž i hledání a nalezení toho, co člověk ztratil. Shrnuto slovy Ignáce Brjančaninova: „Boží rozhodnutí jsou přítomná a účinná uprostřed toho, co dělají lidé i démoni, podobně jako subtilní duch uprostřed bytí, a nezávislý na bytostech, neomezený bytostmi, působící na bytosti a nepodléhající jejich působení. “32

„Církev si je velmi brzy vědoma své vlastní existence coby teologické danosti, což projevuje sebereflexí. ${ }^{\prime 33}$ Představa církve jako velké lodě, již je svěřena péče o naši věčnou spásu, je součástí teologie církevních otců. „Církev je cesta po moři k portus salutis. Církev je nebezpečná a současně nádherná pout: Plná ohrožení, nebot ještě nedorazila do konečného př́stavu, a nádherná, nebot představuje jediné místo vrozené jistoty uprostřed zlého moře. “" Ještě Martin Luther předává pohled na církev vycházející z dogmatického přesvědčení, že nevěřící svět lze „zachránit ve svaté arše křestanství, poskytujíce mu sucho a bezpečí “ ${ }^{35}$ Kritik křestanství a skeptik Celsus v polemice s Origenem hovořil posměšně o „podivuhodné skřŕňce, která v sobě skrývala vše“. ${ }^{36}$ Církev představuje archu, $\mathrm{v}$ níž rodina zachráněných přetrvává potopu světa a také poslední soud přečká stejně, jako přečkala velkou vodu v arše Noemově, jež se jí stala spásonosnou.

Obraz církve jako lodi, která dává bezpečí lidem kolísajícím mezi nadějí a úzkostí, se stal výrazem kulturního, inkulturovaného křestanství prvního i druhého tisíciletí. Svět z pohledu Řehoře Nysského je „ohromné moře Božích úradkư“, ${ }^{37}$ jež se musí učit člověk číst, aby mohl doplout do svého cíle. Kolísavost člověka je jeho údělem, kterému musí čelit novostí obnoveného člověka v Kristu. Ve svém kerygmatickém zaměření se církevní otcové obrací k lidem své doby a připomínají úděl Odyssea, který se nechá přikovat ke stěžni své lodi, aby odolal svádění Sirén. Je to svět, který je z pohledu papeže Inocence III. „hořké moře“ „naplněné sladkým vábením Sirén“. ${ }^{38}$

Zrození Krista ze srdce církve a věŕících je důvodem blízkosti bezpečí plavby životem. V milosti křtu je Kristus zrozen skrze církev v našich srdcích, přičemž se ono zrození stále znovu odehrává

30 GS 5.

31 Olivier CLÉMENT, Transfigurer le Temps. Notes sur le temps à la lumière de la tradition orthodoxe, Paris: Communauté de Taizé Delachaux et Niestlé, 1959, s. 99.

32 Ignatij BRJANČANINOV, Сочинения, sv. 2., Аскетические опыты, С.-Петербург, 1886, s. 83.

33 Jean DANIÉLOU, Théologie du Judéo-Christianisme, Paris: Desclée, 1958, s. 317.

34 Hugo RAHNER, Symbole der Kirche, Salzburg: Otto Müller Verlag, 1964, s. 240.

35 Citováno dle Per LUNDBER, La Typologie baptismale dans l'ancienne Église, Leipzig: Alfred Lorentz, 1942 , s. 1, pozn. 1.

36 ORIGENES, Adversus Celsum, IV, 41.

37 ŘEHOŘ Z NYSSY, In Canticum canticorum homiliae, 12, in: PG 44,1016b.

38 INOCENC III., Sermo 22, in: PL 217,555; Sermo 6, in: PL 217, 617c. 
v životě stále více naplněném milostí. Anima ecclesiastica, řečeno s Origenem, formuje onu tvář církve, která se připodobňuje Kristu. Slovy Huga Rahnera:

„Uvedené učení tak vstupuje do nejtěsnější souvislosti s pojetím církve coby panenské matky a zprostředkovatelky spásy, a to $\mathrm{v}$ nově stvořeném a Kristu připodobněném životě křestní milosti. Avšak učení o Božím zrození z církve a ze srdce věřícího neodvozuje počátek milostí naplněné jednoty v Kristu natolik z jednotlivého milostí obdařeného člověka a z jeho účasti na Těle Kristově jako spíše z jediného Krista, který má ve všech stejnou podobu a který všechny slučuje v jednotu svého Těla, jíž je církev. ${ }^{\text {“39 }}$

Jako červená nit’ se táhne tato podoba církve reflektující sama sebe, svůj život ve světě a své poslání v něm. Tento pohled přináležitosti Krista ke světu se stal základním zorným úhlem ekleziologie prvního tisíciletí i vrcholného středověku. Minucius Felix vidí Kristův kříž ve vojenských praporech, korouhvích i standartách: „Vaše vítězné trofeje mají nejen podobu prostého kříže, ale i člověka na něm visícího. ${ }^{40}$ Ale sama skutečnost př́ítomnosti církve není bez rizika. Na plavbu hořkostí moře světa může vyplout jen ten, kdo sám není ponořen do této hořkosti. Jinými slovy provázejícími vzdělance po celý středověk: „Raději odejděte, Sirény sladké až k záhubě, a zanechte ho mým Múzám, aby ho léčily a uzdravily." ${ }^{\text {‘1 }}$

Od druhého století po Kr. se opakuje Justinova základní dogmatická myšlenka, která čelí stále přítomnému úzkostnému šeptání starých Řeků o „hořkém moři“: „Moře nelze překonat jinak než na lodi s neporušeným tropaionem Kř́iže, stěžněm. ${ }^{“ 42}$ Německý poutník překonává nebezpečí své poutě do Jeruzaléma se slovy Ezzovy písně: „Ty náš vítězný kříži Spasitele, až k nebesưm sahá naše touha po vlasti. ${ }^{“ 43} \mathrm{~A}$ Dante neváhá vyslovit obojí, úzkost i naději:

„Kdo vchází mnou, at naděje se zhostí!“44

„Ó vy, kteřížto ve své bárce malé poslouchat chtiví za mou lodí šli jste, jež zpívajíc si cestu razí dále. “45

Podobně Goethův Faust ústy Mefistofela předjímá úzkost moderní doby, když o člověku říká:

„On by si líp žil o poznání, jen nemít od tebe nebeské záře zdání; rozumem zve ji, což mu znamená, že smí být zvěrštější než zvířena." ${ }^{\text {"46 }}$

Stejně tak zachycuje i naději vyzpívanou chórem kajícnic:

„Příměrem pouhým je

pozemské dění;

co pomíjivé - zde

39 Hugo RAHNER, Symbole der Kirche, s. 13-14.

40 Markus Minucius FELIX, Octavius, 29,8 (v českém překladu: Oktavius, Praha: Ladislav Kuncír. 1940, s. 77).

41 BOËTHIUS, Útěcha z filosofie, 1,1,11 (v českém překladu: Poslední Říman, Praha: Vyšehrad, 1981, s. 50).

42 JUSTIN, Apologie, I, 55,3.4.

43 Christoph LANGE, Das Ezzo-Lied in der Vorauer Überlieferung. Text, Übersetzung und Kommentar, München: AVM - Akademische Verlagsgemeinschaft, 2014. 
v skutek se mění;

co popsat není lze,

jsoucnem tu již;

za věčným ženstvím

jsme neseni výšs. “47

Jen v tomto malém přehledu se nám představuje obraz vnímání světa, $v$ němž člověk byl v duchu křestansko-osvícenské tradice subjektem. Zápasil o své sebe-vědomí tím, že hledal cestu mezi nadějí a úzkostí ve své přítomnosti, a tím vytvářel kulturu ve vztahu k něčemu jinému, vytrhával se $\mathrm{z}$ danosti a setrvačnosti doby.

Poslední vzepětí této civilizační epochy života mezi nadějí a úzkostí jsme v našem českém prostředí měli to štěstí prožívat v 60. letech minulého století, když Ludvík Vaculík svým vystoupením na Sjezdu spisovatelů v roce 1967 ukázal novou podobu prožívání naděje a úzkosti jako znamení doby. Jednalo se o důstojnost socialistického člověka, který nedostatek smysluplnosti života prožíval jako úpadek ideologicky hodnověrné komunistické totality dvojím způsobem: a) monopol moci si uzurpovala vládnoucí komunistická nomenklatura (dnes bychom řekli oligarchie), která neznala nic jiného než kariérismus, klišé a řeč frází; b) život v socialismu se prožíval jako fraška revolučního hnutí a nesmyslnost systému, která nutila poctivé komunisty podvádět nebo popřít sebe sama vyprávěním protirežimních vtipů mezi soudruhy. Znamením doby se stala smysluplná řeč. Vaculík řekl:

„A chci se vrátit k tomu, co si myslím o charakteru každé moci: že její vývoj a chování se řídí jejími vnitřními zákony, na nichž nemůže nic změnit osoba u moci, ani tř́ída u moci, nebot je to prostě zákonitost lidského chování v určité situaci: u moci. Prvním zákonem každé moci je, že chce být i nadále. Reprodukuje se ve stále přesnější podobě. Za druhé se stále homogenizuje, očištuje od nesourodého, až každá její část je obrazem moci celé. (...) Vnitřní zákon moci dává přednost lidem, kteří jsou svým vnitřním ustrojením jako ona. Protože však je jich nedostatek, musí používat i lidí jiných, jež si pro svou potřebu upravuje: vydírá je.

Moc je zvláštní lidské fenomenon dané tím, že už v lesním houfu musí někdo poroučet a že i ve společnosti samých šlechetných duchů musí kdosi shrnout poznatky z diskuse a formulovat nutnost. Moc je specificky lidská situace. Postihuje vládnoucí i ovládané a obé ohrožuje na zdraví. Tisíciletá zkušenost s mocí vedla lidstvo k tomu, že se snažilo určit jakási provozní pravidla." ${ }^{\text {"4 }}$

Znamením doby, jak najít konkrétní cestu vytyčenou polaritou naděje-úzkost, se stala provozní pravidla moci. Tato fascinace smysluplností se stala hybným motorem politických událostí a kultury Pražského jara 1968. Slovy Milana Kundery „nejen střežit hranice, ale také nadřadit epochální zájmy nad momentální zájmy“. Když se jdeme podívat na toto znamení doby do muzea postkomunismu, zjistíme, že se většina návštěvníků dívá na nedávnou minulost jako na nic neříkající obrazy. Staly se součástí „konce světa“, kde člověk vedl zápas mezi nadějí a úzkostí. A který, jak se zdá, je odsouzen nevyhnutelně k damnatio memoriae. Nezřídka, když vstupujeme do roz-

47 Johann Wolfgang GOETHE, Horské rokle, in: Faust, s. 424.

48 @ Ludvík VACULÍK, Projev na IV. sjezdu Svazu československých spisovatelů, Praha 27.-29. června 1967, in: Ludvík Vaculík (on-line), dostupné na: http://www.ludvikvaculik.cz/index.php?pid=56\&sid=36, citováno dne 15. 11. 2015. 
pravy současných protagonistů post-kultury, zůstává v nás jistý silný dotek chladu: Téměř jako by vzdělanec dnešní doby „musel“ rozmlouvat v jakési noční samotě rozumu ponechaného sobě samému, který se živí již od východu slunce úděsným výkřikem pomatence Nietzscheho:

„Hledám boha, hledám boha! (...) Existuje ještě nějaké Nahoře a Dole? Nebloudíme nekonečnou nicotou? Neovanul nás prázdný prostor? Neochladilo se? Nepřichází neustále noc, stále více noci? Nemusíme zapalovat svítilny již dopoledne? Nezaslechli jsme ještě hluk hrobníků, kteří pochovávají boha? Neucítili jsme ještě pach božího rozkladu? - I bohové se rozkládají! Bůh je mrtev! Bůh zůstane mrtev! A my jsme ho zabili! Čím se utěšíme, my vrazi všech vrahư? (...) Vypravuje se ještě, že pomatenec téhož dne vnikl do různých kostelů a zpíval v nich své Requiem aeternam deo. Když ho vyvedli a vyslýchali, odpovídal stále jen toto: ,Čím jsou ještě tyto kostely, ne-li hrobkami a náhrobky boha? “49

Odtud pak vyrůstá stále se vracející otázka: Mohu se jako křestan dneška / teolog dneška pokoušet porozumět dramatickému a zneklidňujícímu běsnění, jež nazýváme „současnou Evropou“, její kulturou, jako znamení doby? Ano, právě proto, že se mne dotýká tak osobně? Nejde o akademické pochopení, ale o situování křestanského života do prostředí, o kterém hovořil sv. Jan Pavel II. v bruselském sídle Evropského hospodářského společenství (20. 5. 1985) nezamlčev těžké stíny, které Evropu pokrývají. Pokrok lidstva - nesený nebývalou expanzí lidské aktivity založené na racionalitě vědy a techniky a prosazování hodnot rovnosti a svobody - vyústil podle něj do situace, kdy „racionalistický optimismus, který člověku vnukají jeho úspěchy, jej přivádí k popření jakéhokoli transcendentního ideálu, který by se vymykal moci jeho vlastního génia. (...) Člověk hledá svobodu, ale utíká před odpovědností. Usiluje o blahobyt, není však schopen se vypořádat s bídou kolem sebe; vyznává rovnost všech a upadá do zajetí rasistické nesnášenlivosti. Bohužel toto všechno, co požaduje pro sebe a co má k dispozici, vede současného člověka k pochybnostem nad smyslem života, k úzkostem a nihilismu. ${ }^{\text {"50 }}$

Ani papež František po třiceti letech nemohl na stejném místě - v Evropském parlamentu - mluvit jinak:

„Jestliže totiž právo každého není harmonicky uspořádáno k širšímu dobru, považuje se nakonec za neomezené, a stává se proto zdrojem konfliktů a násilí. (...) Lidská bytost riskuje, že bude redukována na pouhé soukolí nějakého mechanismu, který s ní zachází jako s nějakým užitečným spotřebním statkem, takže - jak bohužel často vidíme - jakmile její život v tomto mechanismu už neplní funkci, je bez př́lišných zábran skartován jako $\mathrm{v}$ př́ípadě nemocných v terminálním stadiu, opuštěných a nezaopatřených starých lidí nebo dětí zabitých před narozením. “51

Rozdíl mezi mořem hořkosti antického světa a iracionální chamtivostí naší civilizace nacházíme v jiném vnímání prrítomnosti. Jestliže chtěl mnich 6. století po Kr. promyslet, proč se má vrhnout

49 FriedrichNIETZSCHE, Pomatenec, in: Radostná věda 125, Praha: Aurora, 2001, s. 113-115; @ Der tolle Mensch, in: Die fröhliche Wissenschaft 125 (on-line), dostupné na: http://gutenberg.spiegel.de/buch/-3245/6, citováno dne 1. 11. 2015.

50 ๑ GIOVANNI PAOLO II., Alla sede della Comunità economica europea, in: La Santa Sede (on-line), dostupné na: http://w2.vatican. va/content/john-paul-ii/it/speeches/1985/may/documents/hf_jp-ii_spe_19850520_european-comm-bruxelles.html, citováno dne 14. 11. 2015.

51 FRANCESCO, Come ridare speranza al futuro, L'Osservatore Romano 270 (26. 11. 2014), s. 1. 
do barbary zapáleného kláštera a vytáhnout spolu s mnišskými pravidly a liturgickými knihami i spisy antických pohanských filosofů, našel důvod v naději, že tím zachraňuje budoucí svět. Jestliže křestan dneška má učinit gesto srovnatelné, stojí před rozhodnutím vypnout online „žvanění", o kterém již nikdo přesně neví, o co skutečně jde. Valí se na nás v proudu po minutách dávkovaných novinek ze Sýrie, ze života domácích mazlíčků či politického skandálu, aniž bychom vnímali konkrétní podobu deficitu dneška. Co se však stane, nastane-li blackout našeho online propojení s tzv. přítomností? Tato přítomnost nebyla zrozena dnešní mladou generací, ale generací jejich rodičů. Zhoubný bumerang času se stal generační propastí a novou, dosud nenaplněnou prázdnotou.

\section{Rozlišování jako cesta $\mathrm{k}$ naději?}

Papež František, který přišel z periferie katolické církve do jejího samého centra, si přinesl ostré vidění, idiosynkratický styl mluvy, ignaciánskou obrazotvornost a primární důraz zohledňující roli papeže jako biskupa města Ř́ma, který předsedá v lásce celé církvi. Samostatnost jeho teologického uvažování a přirozená inteligence se opírají o životní zkušenost a intelektuální formaci, která není opřena jednostranně jen o akademický trénink. Především si však během svého života osvojil velkou znalost lidského jednání. Kulturně a myšlenkově se vzdělával v prostředí teologie osvobození. Přijal ji za vlastní především ve formě osobní lidové zbožnosti. Opakovaná tvrzení o jeho dogmatické konzervativnosti odvisí od toho, jak kdo definuje teologii osvobození. Podobně jako nemá př́liš zapotřebí zabývat se mimořádnými věcmi, zaujímá rezervovaný postoj - jeho slovy - k utopistickým laboratořm, humanistickým utopiím nahrazujícím Boží království, stejně tak jako $\mathrm{k}$ institucionálnímu formalismu či jiným náboženským klišé. To vše zahrnul pod silný, patristikou inspirovaný výraz církev jako svatá hampejznice. ${ }^{52}$ Co jej skutečně niterně zneklidňuje, je mysterium iniquitatis uprostřed lidského společenství, především chudých. ${ }^{53}$

S př́chodem do Evropy je konfrontován s pohasínáním civilizační epochy života mezi nadějí a úzkostí. Smrákání se dotýká i evropských místních církví. Únava, mátožnost, nedostatek čilosti, to jsou hlavní ukazatele ekleziální institucionalizované lenosti a základní nevěrnosti, která nese strašlivé označení: ekleziální ateismus. Ale již ve svém článku Špatný představený (1983) mluvil Bergoglio o dobré a špatné únavě: „Zdravá únava je ta, kdy pastýř opouští své ovečky utahán $\mathrm{k}$ smrti, ale štastný. Po dnu plném práce přináší své ovečky před svátost oltářní, aby se za ně modlil - ovečky, za které se nestydí, jimiž je nasáklý a které jsou do něho zblázněné. ${ }^{54}$ Papež rozlišuje $\mathrm{v}$ rovině života, $\mathrm{v}$ němž se otevírá jeho smyslu.

Duch obnovuje svůj život rozlišováním. Jím dává vyprahlým kostem tvar života. Křestan dneška skrze rozlišování vnímá to, co přináší vnitřní útěchu, i to, co přivádí člověka do neklidu. Neklid hledání, rozlišování, vhled do věcí, to vše vede křestana k praktickému rozhodování. Pro Bergoglia je typické, že nevidí dramatický rozdíl mezi tím, co vnímáme v našem životě jako vše ustanovující iniciativu z Boží strany, a co vnímáme z naší strany jako vyčerpávající nasazení se pro denní bdělost a věrnost. Neútěšnost totiž působí to, že jsme „vlažnými, lenivými a nedbalými, (...)

52 Srov. Leonardo BOFF, Francis of Rome and Francis of Assisi: A New Springtime for the Church, New York: Orbis Books, Maryknoll, 2014, s. 32-45. Podle názoru sv. Ambrože jsou obě slova oxymóronem: Církev je svatá (casta), ale výraz hampejznice (meretrix) je titul, který církev nehanobí. Oba výrazy ukazují na povahu církve: Uchovává si ryzost a zároveň i ochotu přijímat všechny.

53 Srov. Philip ENDEAN, Writings on Jesuit Spirituality by Jorge Mario Bergoglio, S.J., Studies in the Spirituality of Jesuits 3/2013, s. 7.

54 Jorge Mario BERGOGLIO, The Bad Superior, in: Studies in the Spirituality of Jesuits 4/2013, s. 33. 
a ztrácíme duchovní útěchu vlastní vinou“ ${ }^{55}$ Při tom si máme být vědomi toho, že „není v našich silách získat a uchovat si hlubokou zbožnost, vroucí lásku, slzy nebo jakoukoli duchovní útěchu, nýbrž je to všechno darem a milostí Boha“" ${ }^{56}$ Rozhodování je pro Bergoglia možné jen tehdy, jestliže se rozlišování chápe jako asketické úsilí a nasazení, které dává růst naší disponibilitě a zároveň v sobě obsahuje vysokou míru přizpůsobivosti v jednání. Přitom zde vždy zůstává prostor, který nemůžeme plně ovládat a mít pod kontrolou. Ale to podstatné, co Bergogliovo svědectví přináší, je dalekosáhlé zjištění: Evropská kulturní tradice praktické moudrosti (fronesis) a křestanského rozlišování duchů může přece jen v současné globalizaci čelit povrchnosti, banalizaci a mediální zkratce.

Může otevř́t cestu, jak projít naděje a úzkosti dneška jinak, než cestou rozlišování, očištování a reformy? Zkoumání znamení doby a jejich výklad ve světle evangelia vyjadřuje nově vztah světcírkev. Teologicky se zde otevírá nová citlivost jako pastorální kosmologie založená na stvoření. Zkoumání znamení doby vede k poznání Otce, který provází člověka dějinami. Takto založená pastorální antropologie rozvijí vztah milosti a přirozenosti. Hlavním předmětem zájmu je př́itomnost Stvořitele-Otce ve stvořeném světě at už jako danosti či svobody zakoušené v církvi. Pastorační rozlišování má jiné východisko: Je přítomností Krista jako počátku a dovršení spásy rozlité do celého Kristova těla, to jest církve. Tématem je povelikonoční prítomnost Krista v církvi jako lidsky vnímatelná, zakoušená a duchovní plodnost rozvíjející jednotu božského a lidského. Znamení času jsou pneumatologickým rozměrem života a poslání církve. Ústí do mystiky. Pastorační rozlišování není jen kristologické, ale je kristocentrické. Míří směrem od rozechvění církve dané růstem Kristova těla na cestu k jejímu dovršení v nebeské liturgii. Ústí do askeze.

"Církev ve svém neustálém rozlišování může také rozeznat, že její vlastní zvyklosti, které nesouvisejí př́mo $s$ jádrem evangelia, ale jsou velmi zakořeněny v dějinách, dnes už nejsou interpretovány stejně a jejich poselství zpravidla není vnímáno odpovídajícím způsobem. Mohou být krásné, ale při předávání evangelia neposkytují nyní stejnou službu. Nemějme strach je zrevidovat. ${ }^{\text {“57 }}$

Když papež hovoří o pastoračním rozlišování, dotýká se církve jako té, která rozlišuje. Pro pastorační rozlišování nejsou východiskem kritéria rozlišování nebo rozlišovaného, nýbrž kritéria pro rozlišujícího. Zde promlouvá jako ten, kdo chce dovést k vlastní podstatě rozlišování: „Jsem hřrišník, na kterého shlédl Pán. “58 Papež František schopnost rozlišovat vysvětluje obrazem Povolání svatého Matouše od Caravaggia. Na obraze Ježíšův prst mírí na Matouše, který jen stěží může odtrhnout pohled od peněz, které má před sebou. To byl i Františkův postoj, který charakterizoval jeho přijetí volby: „Jsem hř́šník, ale z milosrdenství našeho Pána Ježíše Krista důvěřuji a s kajícím duchem přijímám. "Tento pohled je klíčový a přivádí služebníka evangelia k tomu, aby vyšel z vlastní temnoty a vstoupil do nové temnoty noci s tím, kdo sestupuje do lidské temnoty i do podsvětí, aby zavolal velikonoční „Adame, kde jsi!“. Rozlišovat neznamená jen dívat se na přicházející znamení. Znamená přimknout se $\mathrm{k}$ tomu, kdo mne povede životem. Boží lid potřebuje nejen ty, kdo umí ćíst znamení doby, ale také ty, kdo doprovázejí kolísající mezi nadějí a úzkostí a neopouští je. Rozlišování neslouží výlučně k poznání, ale k semknutí, sjednocení, objetí. Zde Bergoglio nezapře své ignaciánské charisma:

55 IGNÁC Z LOYOLY, Duchovní cvičení, č. 322.

56 Tamtéž.

57 FRANTIŠEK, Evangelii gaudium, Praha: Paulínky, 2014, 43. Dále pouze EG a číslo příslušného oddílu.

58 U mne je vždy otevřeno. Papež František v rozhovoru s Antoniem Spadarem SJ, Praha: Paulínky, 2013, s. 20. 
„Ignác viděl Krista s křížem na ramenou a vedle něho Otce, který mu říkal: ,Chci, aby sis tady toho vzal za svého služebníka.' Pak se Ježíš obrátil na Ignáce a řekl mu: ,Chci, abys nám sloužil.' Byla mu slíbena Boží ochrana i pro budoucí ŕád. “59

V rozlišování se nejedná o nic jiného, než najít praktickou podobu toho, jak křestan mủže najít Boha ve způsobu užívání věcí. Láska probouzí obrazotvornost, a ta orientuje lidské cítění.

„Toto přesvědčení se však udržuje neustále obnovovanou osobní zkušeností s jeho přátelstvím a jeho poselstvím. Nelze vytrvat $\mathrm{v}$ horlivé evangelizaci, nebudeme-li na základě vlastní zkušenosti přesvědčeni o tom, že poznat Ježíše či nepoznat jej není totéž, že není totéž kráčet s ním, či namáhavě tápat, není totéž moci mu naslouchat či neznat jeho slovo, není totéž mít možnost kontemplovat jej, klanět se mu a spočívat v něm, anebo tuto možnost nemít."60

Rozlišování nemá za cíl přesně rozlišovat, ale nechat mravní svědomí a povědomí láskou ke Kristu podnítit oním směrem, ke kterému člověk tíhne, i když musí vyvinout maximální míru úsilí konat dobro a vyhýbat se zlu. Není neurčité, vždyt i samotné tíhnutí ke spiritualitě může být jen podobou „duchovního konzumismu, který je v souladu s vlastním chorobným individualismem“. ${ }^{61}$ Podobně aktivismus služby $\mathrm{k}$ druhému může být jen zástěrkou, alibi, protože je nutné rozlišit "autentickou opci pro chudé od jakékoli ideologie“. ${ }^{62}$ Rozlišování je vnitřní postoj touhy pomoci druhému, být mu nablízku a zároveň „se učit zout si opánky z nohou před posvátným územím druhého“" ${ }^{63} \mathrm{~V}$ rozlišování člověk umírá sám sobě, důvod rozhodnutí je dán hlouběji než v mém názoru na věc: „, $\mathrm{K}$ tomu, abychom mohli sdílet život $s$ lidmi a velkodušně se dávat, potřebujeme uznat, že také každý člověk je hoden našeho odevzdání. (...) Každá lidská bytost je předmětem nekonečné Pánovy něhy a v jejím životě přebývá sám Pán. “" Rozlišování znamená vstoupit dovnitřr, sdílet intimitu komunikací nesenou přítomností Ducha. „Kdo doprovází, dovede rozpoznat, že situace každého jedince před Bohem i jeho život milosti je tajemství, které nikdo nemůže poznat jen zvnějšku. ${ }^{\text {"65 }}$ Rozlišování překračuje navyklé hranice, poněvadž rozšiřuje náš úhel pohledu o pohled přítomného Pána na „raněný svět“. Prožíváme se všemi lidmi jejich denní zkušenost, navíc jsme skrze rozlišování připraveni otevřít se tomu, že i ostatní hledající „mají své nejzazší vyjádření a svůj pramen v Bohu“ ${ }^{66}$ Rozlišování v sobě nese vnímání postupného zrání času. „Pro dosažení určité zralosti, tedy aby lidé byli schopni činit opravdu svobodná a odpovědná rozhodnutí, je třeba

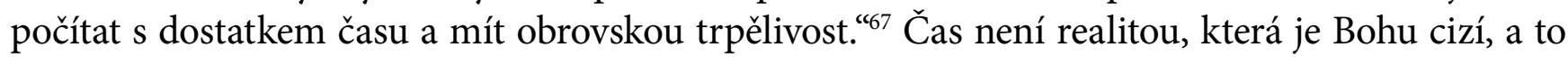
jednoduše proto, že Bůh se chtěl zjevit a spasit nás $\mathrm{v}$ dějinách, $\mathrm{v}$ čase. Význam času, časovost, je atmosférou Božího zjevení, tedy vyjevením mystéria Boha a Jeho konkrétní lásky. Představuje typ toho, kdo rozlišuje. Je neklidným duchem, váhavým a nikdy neuspokojeným. Učí se spojovat svoji nepokojnou, ale také jemnocitnou a vytříbenou citlivost se schopností přijímat rozhodnutí. Kdo rozlišuje, nosí v sobě velké tužby. Objevují-li se těžkosti, podněcují k další činnosti. Rozlišování je projevem opravdové víry, která v sobě zahrnuje hlubokou tužbu změnit svět.

59 IGNÁC Z LOYOLY, Souborné dílo, Olomouc: Refugium, 2005, s. 288.

60 EG 266.

61 EG 89.

62 EG 199.

63 EG 169.

64 EG 274.

65 EG 172.

66 EG 257.

67 EG 171. 
Rozlišování očima papeže Františka je nástroj osobního nasazení, zápasu a celoživotního úsilí na cestě života, jehož smysl se nám otevírá každý den z jeho cíle. Z jeho zaměření můžeme tušit cestu, směr, kterým se musíme vydat. Setba se posuzuje podle toho, k jakým žním nás přivede. Rozlišováním mění člověk svoji podobu: Před rozlišováním člověk „nese podobnost s tím člověkem, který pocházel ze země“ (1K 15,49a). Diky rozlišování „poneseme i podobnost s tím, který je z nebe“ (1K 15,49b). První člověk je „tělo, které podléhá zkáze“ (1K 15,42), druhý člověk se skrze rozlišování, jímž vrůstá do Krista svým cítěním, vnímáním a důvěrností (srov. Fp 2,2), ve svém těle stává tělem Kristovým, a proto přijímá „tělo, které zkáze nepodléhá“ (1K 15,42). Tak se křestan stává znamením doby, svým tělem, sobě určeným a svobodně přijatým lidským údělem, má účast na proměně těla Ježíše Krista, který přijal lidský úděl. Útěk před smrtí, Jonášưv syndrom, se promění v Jonášovo znamení, konkrétní, neodvolatelnou a nezaslouženou milostí vzkříšení těla. A jiné znamení než znamení Jonášovo dáno nebude.

Ve světě a v životě přírody, jež jsou uzavřeným světem a životem, je vše náhodné, bez propojení, nemající žádný význam; člověk v případě, že je jen součástí př́írody, je zbaven smyslu a hloubky a jeho přirozený život je zbaven následnosti významů. Ale člověk jako obraz Božího bytí, to znamená jako symbol božství, má svůj přesný význam a absolutní smysl. Vědomí směřované k božskému světu však otevírá vnitřní zřetězení významu. Obsahuje ukazatele k jinému světu. Toto vědomí je svobodné a přiřazuje smysl zjevné prázdnotě přirozeného světa. Je nemožné prokázat existenci smyslu v životě univerzálním, nelze ji vydobýt racionálně indukcí z přirozeného světa. Zaměřenost přírodních pochodů se zdá být sporná. Nelze odkrýt smysl jinak, než že jsme jej prožívali v duchovní zkušenosti, jinak, než že jsme jej zaměřili k duchovnímu světu. Nemůžeme je prokázat jinak než životem, který je proniknut smyslem, symbolickým vědomím, které jej označuje, spojuje a dává mu význam. ${ }^{6}$

Rozlišováním přijímáme smysl jako nezasloužené obdarování, které je vrcholným projevem svobody. „Vzdáváme se“ svobody, která by určovala smysl mimo vztahovost. Rozlišováním se spolu-obětujeme. Protože na křiži poznáváme v Ukřižovaném vlastní smysl důstojnosti osoby, který nespočívá $\mathrm{v}$ tom, že miluji, ale $\mathrm{v}$ tom, že jsem milován. Až tato novost života otevírá cestu k tomu, abychom kolem sebe pozorovali např́iklad i to, že „jsou tělesa nebeská a jsou tělesa pozemská. Jiný je lesk těles nebeských, jiný těles pozemských. Jinak září slunce, jinak září měsíc, jinak září hvězdy. Dokonce i hvězda od hvězdy se liší leskem“ (1K 15,40-41). Jsou to každodenní umírání sobě samému, která vztyčují v církvi onen stěžeň Kristova kříže jako jediného znamení, v němž je vítězství jisté. To, co je dnes svěřeno církvi jako znamení doby, je lidské tělo určené k proměně.

\section{Od církve zkoumající znamení doby (GS 4) k církvi rozlišující (EG 43)}

\section{Abstrakt:}

Článek reaguje na pocitovanou nutnost vtělovat víru do života, z níž vyplývá také potřeba propojovat teologii s pastorací. Tento požadavek byl hlasitě vysloven na II. vatikánském koncilu, který křestana vyzývá k rozpoznávání znamení doby. Církev Ize vnímat jako velkou lod', jež má lidstvu poskytnout bezpečí a přinést spásu. Soudobý člověk se plaví po moři světa kolísaje mezi nadějí a úzkostí. Právě v tomto kolísání je možné spatřovat znamení doby. Ž̌ejmě však 
nestačí zůstat u něj. Zkoumání znamení doby je spojeno s vnímavostí pro prítomnost Stvořitele-Otce ve stvořeném světě. Jestliže se od něj posuneme k pastoračnímu rozlišování v ignaciánském slova smyslu, stane se ústřední prítomnost Božího Syna jako počátku a dovršení spásy rozlité do celého Kristova těla, to jest církve. Ústředního významu tak nabývá povelikonoční přítomnost Krista $v$ církvi jako zakoušená a duchovní plodnost rozvíjející jednotu božského a lidského. Autor článku ukazuje, že právě skrze rozlišování, k němuž nově zve papež František, může církev člověka vést k naději.

Klíčová slova: pastorace, znamení doby, aggiornamento, rozlišování, naděje, úzkost, člověk, církev

\section{Kontakt na autora}

\section{Prof. Pavel Ambros SJ, Th.D.}

Univerzita Palackého v Olomouci

Cyrilometodějská teologická fakulta, Katedra pastorální a spirituální teologie

Univerzitní 244/22, 77111 Olomouc

pavel.ambros@upol.cz 